\title{
Plastic Pollution in Soils: Governance Approaches to Foster Soil Health and Closed Nutrient Cycles
}

\author{
Jessica Stubenrauch $1,2, * \mathbb{1}$ and Felix Ekardt ${ }^{1,2}$ \\ 1 Research Unit Sustainability and Climate Policy, 04229 Leipzig, Germany; felix.ekardt@uni-rostock.de \\ 2 Faculty of Law, Faculty of Agriculture and Environment, and Interdisciplinary Faculty, Rostock University, \\ 18051 Rostock, Germany \\ * Correspondence: jessica.stubenrauch@uni-rostock.de; Tel.: +49-341-492-77867
}

Received: 20 April 2020; Accepted: 19 May 2020; Published: 20 May 2020

\begin{abstract}
Plastic pollution in soils pose a major threat to soil health and soil fertility that are directly linked to food security and human health. In contrast to marine plastic pollution, this ubiquitous problem is thus far scientifically poorly understood and policy approaches that tackle plastic pollution in soils comprehensively do not exist. In this article, we apply a qualitative governance analysis to assess the effectiveness of existing policy instruments to avoid harmful plastic pollution in (agricultural) soils against the background of international environmental agreements. In particular, environmental and fertiliser legislation relevant to soil protection in the European Union and in Germany are assessed. Regulatory weaknesses and gaps of the respective legislation are identified, and proposals for enhanced command-and-control provisions developed. However, the legal analysis furthermore shows that plastic pollution ecologically is also a problem of quantity, which is difficult to solve exclusively through command-and-control legislation. Instead, comprehensive quantity-control instruments to phase out fossil fuels (worldwide and in all sectors) as required by climate protection law can be effective approaches to tackle plastic pollution in environmental media like agricultural soils as well.
\end{abstract}

Keywords: plastic governance; microplastics; plastic pollution in soils; agriculture; fossil fuels; environmental law; agricultural law; economic instruments; soil health; nutrient cycles

\section{Scope of the Paper}

Plastic materials are used as a mass product of the economy and our daily life due to a wide spectrum of positive characteristics [1,2]. They are light, flexible, non-rusting, and highly persistent. However, the worldwide increase in the mass consumption of plastics, e.g., in the packaging industry, has led to a ubiquitous distribution of plastics in sinks such as the oceans and soils [3-6]. The degradation of larger plastic particles into smaller but still highly persistent particles in the micrometre and also nanometre range intensify the existing sink problem. Particles and fibres smaller than five millimetres are usually referred to as microplastics $[1,4,7,8]$. An additional distinction can be made between primary, production-based microplastics and secondary microplastics that occur either during the use of a product (e.g., tyre wear) or originate from larger plastic particles by enhanced weathering [4]. Thus, once plastic particles have entered the environment, they potentially pose an almost uncontrollable threat to the preservation of ecosystems and their flora and fauna and, not at least, also to human health [9-12]. Furthermore, conventional plastics are based on fossil fuels, which are a major driver of various ecological problems such as climate change and biodiversity loss and, therefore, have to be cut down to zero sooner or later. On the flip side, plastics that are fully biodegradable not only under laboratory conditions but also under current waste management and natural conditions thus far hardly exist $[2,13]$. Apart from that, bio-based plastics that contain "organic carbon of renewable 
origin like agricultural, plant, animal, fungi, microorganisms, marine, or forestry materials" [2] raise further questions regarding their producibility within planetary boundaries.

In the following, the problem of environmental plastic pollution is discussed with a special focus on (agricultural) soils. Soils are a crucial interface in the environment. It is, therefore, likely that pollutants such as micro- and nano-plastic particles that are introduced into the soil can accumulate or be discharged from the soil through, e.g., erosive processes or deep displacement, and thus be transferred to other environmental compartments like the oceans. Harmful effects of microplastics on the soil structure and subsequently on the soil water balance, soil chemistry, soil life, and soil microbiology as well as on root and tissue characteristics of plants are scientifically presumed $[8,14,15]$. Nano-plastic particles can be taken up by microorganisms or attach themselves to the root tissue or penetrate it and thereby change the cell structure of plant roots $[8,15]$. As a consequence, nano-plastic particles can enter the human food chain through the harvest of plants that have absorbed these particles. The corresponding health consequences have not yet been fully assessed $[1,16,17]$. At the same time, the plastic itself can function as a carrier substance for different chemical contaminants and thereby create new distribution pathways in environmental compartments [18]. However, identifying all potential risks that arise with the introduction of plastic particles into soils remains a scientific challenge because of the high complexity of soils. Furthermore, and in contrast to research on the environmental consequences of plastic contamination in aquatic ecosystems, respective research on plastics in soils has thus far received comparably little attention $[16,19,20]$.

This applies even more so to the necessary governance or policy instruments that have to be established to protect soils and the adjacent environmental compartments. Soils provide essential ecological functions and are the key element for food production. This article will, therefore, address the hardly discussed issue of plastic governance with special reference to agricultural soils that are highly important for both ecosystems and food security, which are, in turn, linked to human health. At the same time, agricultural soils are subject to high levels of human-induced contamination.

\section{Methodology}

In the first step, the present paper will deliver a comprehensive review of the relevant literature on plastic soil contamination. In a second step, building on the respective natural scientific findings, a qualitative governance analysis (or steering analysis) will be applied. This qualitative, multi-method governance analysis triangulates various behavioural scientific findings from a wide variety of disciplinary and methodological backgrounds and assesses which policy instruments can respond adequately to certain legal problems.

Knowledge of behavioural motivations of humans is the basis for assessing the effectiveness of policy instruments. Sustainability research requires the development of instruments that have not yet or only under different conditions been implemented in reality and, therefore, cannot be simply observed. Apart from this, a single policy instrument interacts with so many factors, which makes it hard to identify the impact of it [21]. Notwithstanding this, triangulated findings of human motivation have shown that the actors' egoistic calculations, values, emotions, path dependencies, problems of collective goods, conceptions of normality and the interactions between actors are important drivers for the success or failure of governance instruments [21-23]. These behavioural findings, as well as empirical findings, are the basis for the insight that the effectiveness of policy or governance instruments depended on to avoid some typical governance problems, namely rebound effects, sectoral or geographical shifting effects, enforcement deficits or lack of rigour measured against the underlying targets [21,24].

This takes us to the next crucial point. The potential effectiveness of previously used and potential alternative future policy instruments-in this case, to address plastic pollution of soils—can only be measured against some given targets; otherwise, it would be unclear what "effectiveness" actually means. For the sake of the present contribution, some core international binding environmental targets, in particular, the Paris Agreement (PA) [25] and the Convention on Biological Diversity (CBD) [26], 
serve as these targets. The latter requires to preserve the biological diversity, including the biodiversity of soils. Art. 2 Para. 1, of PA aims at limiting the rise in global temperature to well below 2 degrees Celsius and pursuing efforts to 1.5 degrees Celsius compared to pre-industrial levels, which implies a phasing out of fossil fuels within only a few decades in all economic sectors worldwide [27-30]. This massively opposes the mainly fossil-fuel based plastic production and requires a no less ambitious transition to fossil-free agriculture in the future. Further normative standards such as the human right to life, health and ecological subsistence in national, European and international law could be quoted as targets here (see in detail [21]).

With regard to plastic pollution of soils, effective governance instruments need to minimise the input of potentially harmful substances like plastic at its source and implement the required gradual transition to post-fossil agriculture and society in accordance with the PA. On the one hand, avoidance and recycling measures of plastics in the context of a circular economy and substance law are conceivable legal approaches [31]. On the other hand, legislators at national state and European level have chosen a command-and-control approach to address the negative consequences for environmental compartments like water and soil, resulting from the mass use of plastics worldwide. In this article, we will focus on the latter, in particular on the assessment of the soil protection and the specific fertiliser legislation based on the example of the European Union (EU) and Germany. To avoid sectoral and geographical shifting effects, policy instruments should generally have a broad sectoral geographical coverage [32-34]. Thus, a major focus for effective policy instruments in terms of environmentalism should be on a transnational level. At the same time, command-and-control legislation is (partly exclusively) implemented on a national state level, especially with regard to soils. This is why this contribution also takes German legislation into account as an example. However, some of the results on potential legal starting points (see Section 4.3.) and the discussion on enhanced governance options to minimise plastic pollution of soils (see Section 5.) are also transferable to other world regions, since the above-mentioned governance problems are of a fundamental nature.

\section{Major Entry Pathways for Plastics into Soils}

Soils are the basis for food production and are linked to all other environmental compartments. An essential entry path of plastics and especially of microplastics and also nano-plastics into agricultural soils, is via organic fertilisation. It is currently estimated that between 43 and 50 percent of all microplastics introduced into the soils enter it via organic fertilisers [35]. However, at the same time organic fertilisation and nutrient recycling play a major role in closing disturbed nutrient cycles worldwide [34,36,37]. This is because of the energy-intensive production of nitrogen fertilisers, the dependence of many countries on imports of phosphate rock, the increasing contamination of mineral phosphorus fertilisers with heavy metals like uranium and cadmium next to other potentially negative environmental impacts of mineral fertilisation [36,38-40]. Apart from that, organic fertilisation strategies combined with an innovative crop rotation management can enhance the soil carbon storage potential by supplying the soil with organic carbon [41-43]. Thus, besides positive effects on the soil conditions and its natural fertility, organic fertilisation contributes to climate protection. However, a simultaneously increased input of plastic particles into the soil by organic fertilisation offsets these positive synergy effects vehemently. It becomes clear that plastic contamination of organic fertilisers is - next to the potential pollution of the soil-also a major threat to the required circular economy in agriculture and climate protection. However, the number of plastic particles introduced into the soil varies considerably depending on the specific type of organic fertiliser, as will be shown in detail in the following.

In addition to organic fertilisation mulch films, plastic covers or protective roofs, water hoses or the flooding of areas (especially grassland or floodplains) with river or lake water [16,20], are sources of plastic pollution of agricultural soils. Furthermore, plastic is introduced into soils via atmospheric deposition, where tyre wear plays a major role next to artificial turf surfaces for football matches or other purposes $[4,44]$. 


\subsection{Sewage Sludge}

The highest scientifically proven source of microplastic input into the soil is the direct application of sewage sludge for agricultural fertilisation [45]. About 90 percent of the microplastic contained in the wastewater is retained during the treatment process and accumulates in the sewage sludge [46-48]. Apart from that, synthetic polymers are regularly added during the drainage and treatment process of the sewage sludge [49]. Depending on the frequency of sewage sludge fertilisation, it is estimated that between 0.2 and 8 milligrams of microplastics per hectare per inhabitant are released into agricultural soils in Europe annually [50]. It is, therefore, to be welcomed-also because of other pollutants in sewage sludge- that in Germany, the direct soil-related spreading of sewage sludge will be largely prohibited in the future by the respective command-and-control legislation (see Section 4.2.3.). However, the question of soil-related sewage sludge utilisation is discussed quite controversially. This is because of the energy-efficient and very straightforward possibility to return nutrients to the field [51,52]. Yet, the potentially high contamination of sewage sludge with a wide variety of pollutants and microplastic particles has already led to an increased focus on indirect, thermal sewage sludge recycling in Germany and the EU. The direct recovery of essential nutrients such as phosphorus from sewage sludge by specific (preferably energy-efficient) recycling processes is, therefore, seen as future-oriented $[53,54]$. This would also lead to reduced plastic pollution of agricultural soils.

Irrespective of this, the supply of plastic into the sewage systems as a whole should be reduced at the source in order to prevent possible environmental pollution already at this point. This is important because also in Germany only sewage sludge from large sewage treatment plants (larger than 50,000 or 100,000 inhabitants) will be excluded from direct agricultural utilisation in the future (see Section 4.2.3.).

\subsection{Bio-Waste}

The usage of bio-waste and, in particular, composted organic material as fertiliser can also be a relevant entry path for plastics into soils. At the same time, compost fertilisation supplies the soil with organic carbon and has positive effects on soil fertility, soil structure and the potential sink capacity of the soil as a carbon pool and should, therefore, be increasingly used for fertilisation $[55,56]$. However, bio-waste of private households is often not carefully separated or not properly disposed of in plastic bags made of high-density polyethylene $[16,57,58]$. In addition, commercial bio-waste can also be contaminated with plastic, although less frequently on average [16]. In the latter case, plastic packaging of overlaid or spoiled food, which was not unpacked before composting, is an essential input path [57]. Once plastic particles have entered the bio-waste they can hardly, if at all, be removed technically $[45,57]$. This applies in particular to the smallest plastic particles and also to the so-called biodegradable plastic because of the comparatively short process time in the composting plants $[16,35,59]$. Most plastics labelled as biodegradable only decompose at consistently high temperatures above $50^{\circ} \mathrm{C}$ for a longer period of time than provided for in composting plants (or constant UV radiation) [10]. This regularly also applies to bio-based plastics, where organic carbon serves as raw material for plastics production, e.g., from maize or sugar cane [2,60]. The required land and resource use for biomass production additionally limits the possibility to produce bio-based plastics [22,61]. Thus, plastics labelled as biodegradable are thus far not an alternative for household waste disposal or food packaging. It becomes rather clear that reducing the amount of plastic at the source is inevitable. This is also true for oxo-degradable plastics that combine conventional plastics with bio-based plastics $[48,62]$. Oxo-degradable plastics fragment easily into microplastics and are, therefore, considered as a major source of the latter [48,62]. This is why in the EU, single-use plastic products from oxo-degradable plastics are prohibited Art. 5 Directive EU 2019/904 [63].

\subsection{Digestates}

Digestates, which result from the fermentation process of biomass (e.g., liquid manure or energy crops from maize), usually contain very little or no plastic particles [45]. Nonetheless, as with sewage 
sludge, synthetic polymers can also be intentionally added for the treatment of liquid digestates. However, biomass production for energy use is ambivalent in terms of climate, biodiversity and resource protection [22,64]. At the same time, achieving the climate target of the Paris Agreement requires a significant reduction in livestock farming [33]. Thus, manure surpluses that can be fermented will not or only be available to a limited extent in the future.

\subsection{Mineral Fertilisers}

Mineral fertilisers can contain intentionally added microplastics. Microplastics as soil additives promise to loosen the soil substance and enhance water retention with positive effects on plant growth [65]. Apart from that, microplastics build coatings around mineral fertiliser particles to avoid lump or dust formation (anti-caking) under the influence of moisture or heat $[65,66]$. Furthermore, "controlled released fertilisers" - to which microplastics have been added-promise perfect timing of the nutrient release to the plant and thus a high nutrient use efficiency [35]. However, at the same time, the European Chemicals Agency (ECHA) estimates that a ban on additionally added microplastics to fertiliser additives and controlled released fertilisers could reduce emissions of microplastics by approximately 262,500 tonnes in average within 20 years in Europe (range of 67,500 to 442,500 tonnes), which is high compared to the significantly lower emissions savings potential, e.g., from added microplastics in cosmetics [35].

\section{Status Quo and Assessment of the Governance Effect of the Existing Legislation}

\subsection{Soil Protection Legislation}

As there is no comprehensive EU regulation on soil protection, the German soil protection legislation, consisting of the Federal Soil Conservation Act (BBodSchG) [67] and the associated Federal Soil Protection Ordinance (BBodSchV) [68], will be examined below. The BBodSchG aims to sustainably secure or restore soil functions and prevent harmful soil changes in accordance with the precautionary principle ( $\S \S 1,7$ BBodSchG). According to $\S 2$ BBodSchV, pollutants are defined as "substances and preparations which, due to their harmfulness to health, their longevity or bioavailability in the soil or due to other properties and their concentration, are capable of damaging the soil in its functions or causing other hazards" (translated by the authors). Thus, the scope of protection of the BBodSchG according to legal text interpretation also includes potentially harmful soil changes caused by the introduction of plastics. Plastics can be subsumed under the pollutant definition of the BBodSchV because of their potentially harmful effects and their high persistence (see Section 1). According to the systematic of the BBodSchV there is a harmful change in the soil if the defined precautionary values are exceeded (§ 8 Para. 2 No 1 in conjunction with $\S 9$ Para. 1 No 1 BBodSchV). However, precautionary values as well as specific test and measurement values are thus far only laid down for heavy metals and certain organic substances but not for plastics (Annex 2 No 4 BBodSchV). Thus, despite the described identification of plastics as a pollutant according to the BBodSchV, soil pollution by plastics is not integrated into the systematic of the German soil protection legislation. An amendment of the respective legislation would, therefore, be a necessary next step to secure soil health. However, this demands a comprehensive risk assessment of the ecotoxicological effects of plastics in soils first, which in turn requires the development of suitable analytical methods that thus far are highly controversially discussed [69-73]. The need for further research in this respect can be highlighted.

Irrespective of this, with regard to agricultural soils, it is decisive that soil protection law is subsidiary to the specific legal acts (lex specialis) listed in § 3 Para. 1 No 1-11 BBodSchG. This applies inter alia to German and EU fertiliser, waste and circular economy legislation. Thus, the extent to which precautionary soil protection against potentially harmful inputs of plastics can be established depends on the design of the specific legislation considered in the following and the coherence achieved with the soil protection legislation. 


\subsection{Fertiliser Legislation}

\subsubsection{EU Level}

Regulation (EC) No 2003/2003 [74] establishes the provisions for the marketing of mineral fertilisers in the EU thus far. According to Art. 3 Regulation (EC) No 2003/2003, only mineral fertilisers listed in Annex 1 can be distributed in the EU. Intentionally added microplastics to mineral fertilisers are permitted without further restrictions.

The new EU Fertilising Products Regulation [75] will enter fully into force on 16 July 2022. In accordance with the EU circular economy package, the regulation covers for the first time organic and recycled fertilisers from secondary raw materials and other fertilising products. Different product function categories (PFCs) (organic, organo-mineral and mineral fertiliser) are established. Respective quality criteria and material requirements to be met by the PFCs are defined in Annex 1. Additionally, Annex II introduces 11 component material categories (CMCs), including composts and digestates (CMC 3 and CMC 5) as well as polymers other than nutrient polymers (CMC 9). Annex II is a conclusive list that covers the characteristics and qualitative requirements of all possible input materials. The list does not contain sewage sludge. Instead, phosphorus recyclates, such as, e.g., struvite obtained from sewage sludge ashes, should be fostered and benefit from easier EU wide market access. However, the regulations of the EU Sewage Sludge Directive [76] that still allows the direct application of sewage sludge on agricultural soils remains unchanged in this respect (see Section 4.2.3.).

With regard to composts and digestates (CMC 3 and CMC 5), macroscopic impurities above two millimetres (including plastic, glass or metal) shall not exceed a limit of three grams per kilogram of dry matter (g/kg dry matter). From 16 July 2026, this limit-value is lowered to $2.5 \mathrm{~g} / \mathrm{kg}$ dry matter and is going to be reassessed on 16 July 2029 in order to evaluate the progress of separate bio-waste collection. The sum of all the macroscopic impurities shall not exceed $5 \mathrm{~g} / \mathrm{kg}$ dry matter (Annex II CMC 3, No 4 b, c and Annex II CMC 5, No 5 b, c EU Fertilising Products Regulation). Training of employees is also required to ensure the control of the raw materials (Annex IV module D1 5.1.3.1. $\mathrm{d}$ EU Fertilising Products Regulation). However, plastic particles smaller than two millimetres are not covered by the regulation at all and a reinforcement of the law is not foreseen. Thus, a considerable regulatory gap exists on the EU level.

CMC 9 concerns polymers other than nutrient polymers. According to CMC 9 No 1 fertilising products may contain synthetic polymers (a) to control the release of nutrients, (b) to increase the water retention capacity or wettability of them or (c) to bind material in them. Only from 16 July 2026 polymers have to pass an earthworm acute toxicity test to prove their harmlessness for animal and plant health and the environment, and have to comply with the biodegradability criteria according to delegated acts referred to in Art. 42 Abs. 6 Fertilising Products Regulation (CMC 9 No 2). Art. 42 No 6 a establishes that the polymer has to be "capable of undergoing physical and biological decomposition in natural soil conditions and aquatic environments across the Union, thus that it ultimately decomposes only into carbon dioxide, biomass and water." In addition, according to Art. 42 No 6 c polymers should not lead to an accumulation of plastics in the environment. Apart from that, Art. 42 No 6 requires the Commission to reassess the biodegradability criteria for polymers until 16 July 2024. Up to now, the biodegradability of synthetic polymers as required by Art. 42 No 6 a is regularly not given. Thus, synthetic polymers will probably be excluded from the list under CMC 9 after July 2024. However, given the comparatively high emissions and certain negative environmental effects of plastics in soil and the danger of their accumulation, it is incomprehensible why a ban on microplastics as additives for fertilisers is not considered earlier. ECHA assumes that-like other persistent, bioaccumulative and toxic (PBT), and very persistent and very bioaccumulative (vPvB) substances-any release of microplastics into the environment is a risk. Therefore, ECHA calls for a ban on additionally added microplastics - including in fertilisers - in the future [35]. Yet, to ensure that manufactures can adapt their products, i.e., controlled-released fertilisers "a relatively long (5-10 years) transitional period" [35] 
is proposed, while, e.g., for anti-caking agents in fertilisers (regulated under REACH [77]) a shorter time period is assumed to be sufficient [35].

In this context it is again important to note that, in light of Art. 2 Para. 1 PA and the objectives of the $\mathrm{CBD}$, the usage of mineral fertilisers have to be significantly reduced to a minimum in the future. However, the amended EU fertiliser regulation does not consistently reflect this necessity either and instead continues to promote the use of mineral fertilisers in parallel markets to a large extent [78]. In any case, also with regard to recycled $P$ fertilisers and liquid digestates, it will be important to produce/process fertilisers without intentionally adding microplastics in the future. Therefore, clear guidelines-and a potential ban-remain necessary. This applies in particular as far as an improved soil structure and nutrient uptake by plants can also be achieved by other measures of good agricultural practice (e.g., conservation tillage, lower tyre pressure of agricultural machinery, locally adapted diversified cultivation, smart crop rotation, enhanced organic and green fertilisation strategies) (with further references $[36,79]$ making the intentional adding of microplastics to controlled released fertilisers unnecessary.

\subsubsection{Germany}

In Germany, the German Fertiliser Ordinance (DüMV) [80] establishes the rules for the marketing of fertilisers. The addition of synthetic polymers to fertilisers is allowed in accordance with Annex 2 No 7.4.7, No 8.1.3 and 8.2.9 DüMV.

Synthetic polymers that are used to increase the water retention capacity of soils shall not exceed the application rate of 150 kilograms per hectare (kg/ha) in 3 consecutive years and have to be labelled accordingly (Annex 2 No 7.4.7 DüMV). Synthetic polymers that are used to regulate the water balance or wettability of fertilisers, or are used for anti-caking purposes during the processing of fertilisers and do not degrade by at least 20 percent in 2 years have to be labelled as well (Annex 2 No 8.1.3 DüMV). In that case, only a maximum of $45 \mathrm{~kg} / \mathrm{ha}$ of the active substance is allowed to be applied in other than closed systems in 3 consecutive years. However, according to $\S 9 \mathrm{a}$ of the DüMV, by 31 December 2019 , the requirements for synthetic polymers were to be reassessed- "taking into account the latest scientific findings" - and in accordance with the scope of $\S 1$ of the German Fertiliser Act (DüngG) [81]. According to $\S 1$ No 3 DüngG, this includes "to prevent or avert risks to human and animal health and to the natural environment". Therefore, the required total ban of highly persistent synthetic polymers such as microplastic as additives to fertilisers could be integrated into the DüMV soon. Due to the corona crisis, the reassessment has not been published until now.

The DüMV also establishes limit-values for macroscopic impurities such as plastics. Since the amendment of the DüMV in October 2019, all particles larger than one millimetre-rather than previously two millimetres-are covered. A distinction between non-deformable plastic components (hard plastic) and other (deformable, foil-like) plastic components is drawn (§ 3 Para. 1 No 4 DüMV). In a previous reform of the DüMV in 2017, the limit-value for the very light, deformable foil-like plastics was already reduced from more than 0.5 percent by weight of dry matter to 0.1 percent by weight of dry matter ( $\$ 3$ Para. 1 No 4 c DüMV). For all other macroscopic impurities and hard plastics, the limit-value is 0.4 percent by weight of the dry matter ( 33 Para. 1 No $4 \mathrm{~b}$ DüMV). The reduction of the weight proportion for foil-like plastic particles on the one hand and the extension of the scope of application, i.e., the particle size, on the other hand, are positive steps to reduce the input of plastics into the soil. However, micro- and nano-plastic particles with a size of less than one millimetre still remain unregulated. Besides that, from 2022 onwards, all composts and digestates labelled as "EC fertilisers" will be subject to the comparatively weaker limit-value provisions of EU Fertilising Products Regulation (§ 2 Para. 1 DüMV), which again only covers particles larger than two millimetres (see Section 4.2.1.). Thus, in this respect, the aforementioned achievements of DüMV regarding limit-values for plastics as well as potentially further restriction of the usage of synthetic polymers remain toothless.

Irrespective of this, the question of the best possible analytical detectability of micro- and nano-plastic particles in organic fertilisers remains unanswered [45]. However, next to the testing 
on ecotoxicological effects of microplastics in soils [71-73] this is an essential prerequisite for the definition of stricter limit-values in command-and-control legislation. With regard to the methodology for determining the weight proportion of plastics, i.e., larger than one millimetre, reference is currently made to the provisions of the Federal Compost Association [82]. In a first step, sieving determines the total gravimetric content of macroscopic impurities larger than one millimetre. The identified plastic particles are then manually separated into deformable (foil-like) and non-deformable (hard plastic) parts and weighed [82]. However, this process is combined with a very high cost and control effort, which would rise even further as a result of a stricter limit-value setting if no new methodologies are found. In addition, there are no analytical methods to determine nano-plastic particles in the environment $[83,84]$. Thus, two different aspects can be derived: On the one hand there is an importance to develop innovative analytical methods for identifying micro- and nano-plastic particles in organic fertilisers (and soils) and on the other hand, there is a need to effectively minimise the input of plastic at the source by overarching government instruments.

\subsubsection{Specific Regulations for the Agricultural Use of Sewage Sludge}

At EU level, the Sewage Sludge Directive [76] sets the regulatory framework for the (ambivalent) agricultural use of sewage sludge, sewage sludge mixtures and sewage sludge compost. Harmful effects on soils, vegetation, animals and humans should be prevented, and the correct use of sewage sludge encouraged (Art. 1 Sewage Sludge Directive). Annex I of the Directive determines limit-values for heavy metals on the basis of which maximum application rates depending on the quality of the sewage sludge and the soil are laid down. In contrast, contamination with solid particles such as microplastics is again not covered by the directive. Also, EU-wide restrictions of the direct application of sewage sludge as fertiliser are not established.

In Germany, the Sewage Sludge Ordinance (AbfKlärV) [85] applies next to the DüMV. The AbfKlärV was amended in 2017 as part of the Federal Government's Resource Efficiency Programme II [86]. From 1 January 2029, sewage sludge from wastewater treatment plants, which comprises waste streams of more than 100,000 inhabitants, will no longer be permitted for direct use as fertiliser. From 1 January 2032, this also applies to wastewater treatment plants of more than 50,000 inhabitants (Art. 5, 6 Ordinance on the reorganisation of sewage sludge recycling [87]). Simultaneously, from 2029 and 2032 onwards, an obligation to recover phosphorus from sewage sludge that contains at least 20 grams per kilogram $(\mathrm{g} / \mathrm{kg})$ dry matter of phosphorus is established. However, direct utilisation of sewage sludge for fertilisation remains permitted until 2029 and for smaller municipalities also in the long-term future (§ 3 Para. 2 AbfKlärV). Nevertheless, the restriction of the direct use of sewage sludge as fertiliser and the promotion of nutrient recycling encourage the establishment of a circular economy and, at the same time, minimise microplastic inputs into the soil. However, long transition periods until 2029 and 2032 respectively prevent rapid change and thus do not limit the largest input path of microplastics into agricultural soils in the near future. At the EU level, it is questionable to what extent the Committee for Adaptation to Technical and Scientific Progress under § 14 Para. 1 Sewage Sludge Directive might consider a similar withdrawal from the direct use of sewage sludge as fertiliser throughout Europe in the future. Yet, against the background of the comparably high contamination of sewage sludge with a variety of other pollutants in addition to microplastics, this would be a desirable step.

\subsubsection{Specific Regulations for the Agricultural Use of Bio-Waste}

Art. 10 Para. 2 in conjunction with Art. 11 Para. 2 Directive 2008/98/EC [88] determines that waste shall be collected separately. By 31 December 2023, Member States have to ensure that "bio-waste is either separated and recycled at source, or is collected separately and is not mixed with other types of waste", what enables their use as fertiliser (Article 22 No 1 Directive (EU) 2018/851 [89]). The recycling rate of municipal waste shall be increased stepwise from a minimum of 55\% by weight by 2025 to $60 \%$ by weight by 2030 to 65\% by weight by 2035 (Art. 11 Para (2) No c-e Directive (EU) 2018/851). 
In Germany, § 9 of the circular economy law (KrWG) [90] requires the separation of waste and prohibits the mixture of waste. At the same time, the obligation to handover waste for disposal applies (§§ 17, $20 \mathrm{KrWG).} \mathrm{With} \mathrm{regard} \mathrm{to} \mathrm{commercial,} \mathrm{municipal} \mathrm{waste,} \mathrm{§} 3$ Para. 1 No 7 of the Commercial Waste Ordinance (GewAbfV) [91] establishes the separate collection of bio-waste in accordance with $\S 3$ Para. 7 KrWG.

As lex specialis, the Bio-waste Ordinance (BioAbfV) [92] next to the DüMV provides the requirements under which bio-waste such as compost and digestates may be used as fertilisers. According to $\S 4$ Para. 4 BioAbfV, the proportion of macroscopic impurities, including plastic particles of more than two millimetres, shall not exceed 0.5 percent by weight of the dry mass. This limit-value has not yet been adjusted to the revised DüMV, thus that the stricter limit-value of the DüMV applies. Yet, the (legally non-binding) limit-value for deformable plastics for certified quality composts in accordance with the Federal Compost Association amounts only to 0.01 percent of dry matter [57]. Thus, the voluntary use of certified composts would lead to a minimised load of microplastics into the soils.

Moreover, the BioAbfV does not limit the total amount of microplastics that may be applied with the use of bio-waste as fertiliser. This has thus far only been regulated for heavy metals: According to $\S 6$ Para. 1 BioAbfV, depending on the heavy metal content, either a maximum of 30 tonnes per hectare ( $\mathrm{t} / \mathrm{ha}$ ) or only $20 \mathrm{t} / \mathrm{ha}$ shall be applied to the soil over a period of 3 years. At the same time, it is prohibited to apply bio-waste to the soil if the precautionary values for heavy metals, according to the BBodSchG, are exceeded (§ 9 Para. 2 BioAbfV). However, a corresponding reference cannot be established for plastics, as respective precautionary values according to the BBodSchG yet do not exist (see Section 4.1.). Hence, it is questionable whether the BioAbfV should at least integrate a categorisation for the maximal applicable amount based on the plastic pollution of the bio-waste or if it is sufficient to completely exclude bio-waste with particularly high plastic contamination from agricultural use as fertiliser. From the perspective of nutrient cycling, it would be desirable if a potential maximum of the generated bio-wastes could be used for fertilisation. Yet, this firstly requires again a stringent reduction of plastic inputs into bio-waste at the source and secondly, a re-examination of the limit-values for plastics in fertilisers based on bio-waste.

Annex 2 No 8.3.9 DüMV determines that "avoidable" packaging or packaging components are not permitted in compost or digestates. Instead, these have to be separated from the bio-waste before the first biological treatment process. However, the term "avoidable" has not been further specified. Therefore, it is refutably assumed that the unpacking of the packaging, which has direct contact with the foodstuffs is technically impossible or economically unreasonable, while a case by case decision shall always be made for sales packaging that has no direct contact with foodstuffs. Only in the case of other packaging, in particular transport or outer packaging, it is presumed that removal is technically possible and economically reasonable [93]. However, this interpretation is opposed to the desired recycling of bio-waste and its maximum utilisation as fertiliser. Thus far, in Germany alone, the members of the Federal Compost Association collect more than 730,000 tonnes of mostly plastic-packaged food waste from retail every year, which is separately registered via the commercial waste collection and usually processed in biogas plants [57]. It becomes clear that, besides the necessity to minimise food waste [94,95], a reduction of plastic packaging of foodstuffs needs to take place at the source in order to reduce the overall plastic burden on composts [96]. With regard to the latter, the revised EU Packaging Directive [97] is of particular relevance. The directive establishes provisions for reusable packaging and higher recycling quotes and, among others, an "extended producer responsibility scheme" in accordance with Art. 8 and 8a of Directive 2008/98/EC. However, the Packaging Directive lacks precise requirements and binding obligations to avoid plastic packaging in the future. Furthermore, there is considerable scope for national implementation [31]. At the same time, phasing out fossil fuels could contribute significantly to reducing the overall share of mineral oil-based packaging (see Section 5.). In contrast, keeping bio-wastes free of plastic through information campaigns and education alone is 
probably not sufficient, especially since such campaigns would show no effect on the plastic-packaged food that is thrown away at the trade level, e.g., by supermarkets.

\subsection{Assessment of Governance Effects}

It has been shown that, in addition to soil protection law, the examined lex specialis does not yet ensure adequate protection of agricultural soils against pollution with microplastics. In soil protection legislation, precautionary, test or measurement values that legally classify the level of contamination of the soil with plastics do not exist on the national state level in Germany. Additionally, due to the subsidiarity of soil protection law in Germany, a sufficient governance effect could only be achieved if a harmonisation of lex specialis would take place, or if subsidiarity of the soil protection legislation could be overcome. Furthermore, because there is no EU Soil Framework Directive, no EU-wide targets are established to achieve good status of soils-without plastic contamination. Thus, a framework for the assessment of plastic pollution in soils is missing in current regulatory provisions. This is why a corresponding amendment of soil protection legislation has to be discussed and needs to be pursued further in the near future. However, because amongst others, the respective scientific research is still in its early phases and thus firstly needs to be promoted further, such a change in the German soil protection legislation is not to be expected soon. The same applies to a renewed adoption of an EU Soil Framework Directive, which is highly unlikely after its rejection in 2014 [98]. EU-wide standards that address plastic pollution of soils thus seem to be a long way off. However, at the same time, these amendments would not stimulate the necessary absolute reduction of the plastic input at the source thus that further legal instruments are required (see Section 5.).

Regarding the plastic pollution of organic fertilisers, the German fertiliser legislation sets (even stricter) limit values for easily deformable plastics and hard plastics, including particles up to one millimetre. Nonetheless, from 16 July 2022 onwards, the weaker regulations of the EU Fertilising Products Regulation, which cover only particles up to two millimetres, will apply to composts and digestates. As a result, a large proportion of micro- and especially nano-plastic particles have not yet been legally considered, and it seems likely that they will continue to be insufficiently regulated in the future in the EU. Consequently, these particles will presumably continue to be increasingly introduced into the soil leading to negative environmental consequences. Besides that, negative impacts for plants and humans are to be expected.

A total ban on the intentional addition of synthetic polymers to mineral fertilisers or as part of the processing of sewage sludge and digestates does not exist as well and should thus be promoted. Indeed, in Germany, such a ban seems likely within the framework of the DüMV in the near future. However, even if the addition of synthetic polymers to fertilisers would be prohibited in Germany, this regulation would not apply to fertilisers that are approved in accordance with the fertilising regulations at EU level and would, therefore, be largely ineffective. In this respect, the marketing of mineral fertilisers serves as an example: It is a common practice to market them in accordance with European regulations [99] in order to circumvent stricter national limit values for heavy metals such as cadmium. Yet, according to the new EU Fertilising Products Regulation, a ban on intentionally added synthetic polymers cannot be expected within the next four years.

Finally, improved regulations are required to address the issue of (thus far under natural conditions virtually non-existent) biodegradability of plastics. The existing requirements have to be tightened and adapted to the conditions in the natural environment.

All of these aspects remain relevant even if the necessary phase-out of fossil fuels required by Art. 2 Para. 1 PA would be effectively implemented.

\section{Discussion-Enhanced Governance Options}

Until now, the status quo of the policy instruments to protect in particular agricultural used soils from harmful plastic inputs has been assessed, including some alternative regulatory options in 
detail. In addition, in favour of a circular economy in agriculture and the phasing out of fossil fuels, some important further and more overarching points can be made:

1. Environmental and fertiliser legislation aims to minimise inputs of plastics into the environment through command-and-control approaches at certain points, mainly by imposing legal limit-values for macroscopic impurities like plastic. However, the hazard prevention and precautionary measures aimed for in this context are designed in a comparatively punctual and non-comprehensive manner. Above all, limit values do not cover plastic particles of less than one or two millimetres.

2. Nonetheless, it has been shown that extending and sharpening the existing legal instruments in various details is possible without major regulatory efforts. For example, the requirements for organic fertilisers contaminated with plastic could be tightened. Besides that, the intentional addition of microplastics, both during the processing of organic fertilisers and to improve mineral fertilisers, could easily be prohibited by command-and-control legislation in the near future.

3. However, to only focus on this, which the current political, social and scientific debate on plastics regularly does, is most probably insufficient. Instead, it has been shown repeatedly that a key aspect of the future plastic governance is to consistently minimise plastic inputs effectively at the source. At the same time, there is an obligation under Art. 2 Para. 1 PA and human rights, which are based on an understanding of precaution, to phase out fossil fuels in not more than two decades, worldwide and in all sectors. Thus, when merging these two arguments, it becomes clear that no matter how incomplete the regulatory approach on plastics appears to be to date, the mere improvement of details is insufficient. Instead, a governance approach preferable at the EU level (and ultimately worldwide), that achieves the phasing out of fossil fuels is required.

4. Elsewhere it has been shown that such a governance approach could be designed most effectively as quantity control instrument: Within the EU as an upstream emissions trading system that integrates all fossil fuels, takes old certificates out of the market and incorporates a cap that is aligned with Art. 2 Para. 1 PA. In addition, border adjustments for countries that do not choose to adopt a similar approach will be necessary $[21,22,33,40,100]$. It has furthermore been shown that the transnational character of fossil fuels, as well as typical governance problems of command-and-control law to limit quantities (such as rebound effects, sectoral and geographical shifting effects, problems of depicting and enforcement), could be addressed most effectively this way. Therefore, because of the diffuse load of plastic discharges, the excessive use of plastics, the difficulties in recycling and the combination of various environmental problems, effective plastic governance could be achieved in a joint approach that implements a quantity control on fossil fuels.

5. This could significantly reduce plastic pollution at the source and thus help to gain plastic free organic fertilisers and thereby foster circular economy approaches in agriculture and healthy soils in the long term. And even if the phasing-out of fossil fuels was limited to other sectors, it would have an influence on plastics. As fossil fuels start to phase out of use for other applications, plastic production is likely to become more expensive. Part of the reason plastic is so cheap to produce is that it utilises otherwise mostly waste material from the fractional distillation of crude oil for fuels etc. [101]. Nevertheless, a complete fossil phasing-out is more in line with Art. 2 Para. 1 PA (as well as other options such as plastic taxes).

6. However, a phasing out for fossil fuels that would end the current, predominantly fossil-based plastics production, would also raise important follow-up questions. Plastics are not always easy to reduce or replace in many economic sectors due to scarcity of resources (e.g., land, fertiliser, etc. for bio-based plastic productions) and difficulties regarding technologies. Thus, occurring follow-up questions are not only of an economic and social nature, but also of an ecological nature. For example, only focussing on the phase out of fossil fuels might lead to a strongly increased demand for land for the production of bio-based plastics in very large quantities. This could, rather than reducing pressure on the environment, increase the existing agricultural problems and 
thus inhibit circular economy approaches. Therefore, the aforementioned fossil fuel regulation has to be combined with other quantity control elements for land use (and livestock farming to minimise overall land-use pressure) $[21,22,33]$. For example, forests would probably also have to be subject to quantity control legislation because many plastic substitutes are based on trees. However, at the same time, intact forests function as carbon sinks and are biodiversity hotspots and should, therefore, be preserved or managed sustainably. As a consequence, the regulation of fossil fuels for plastics (unlike in the electricity sector, for example) would probably not only trigger technical substitution, recycling and efficiency strategies. Moreover, it would also lead to frugality to a very considerable extent. Therefore, the regulation of plastics serves as a good example, which reveals that the current growth-based economic approach is facing outstanding questions if sustainability approaches that are in line with the Paris Agreement and human rights are pursued. This is particularly true since, in contrast to substitution and efficiency strategies, frugality strategies question in particular the growth orientation of modern economic activity (including all follow-up questions, for example in social security or the labour market [21]).

7. Even if these legal steps were taken, there would still be a considerable need for regulation in plastics law. However, the current challenges would then be significantly reduced, not at least because a complete or even approximate substitution of today's fossil-fuel-based with plant-based plastic quantities could hardly take place due to a shortage of available land. Nonetheless, the discharge of bio-based plastics into the environment-at least as long as they are not fully biodegradable, as is often the case today-is likely to pose similar problems as currently. The introduction of precautionary values for plastics on the basis of their persistence should, therefore, in any case, be continued to be discussed. Alternatively, there is the option of pricing biobased plastics or integrating this into a land-use pricing system that is to be further developed for various ecological reasons.

8. The obligation to take far-reaching measures on plastic on the basis of human rights implies at the same time that such measures are legitimate when weighed against the fundamental rights of companies and consumers. The same applies to the question of whether purely national measures would be compatible with the free movement of goods in the EU. The nature of the quantity problem, however, argues in favour of EU-wide solutions and only subsidiarity in favour of national approaches, although the latter might be easier to implement (see in detail [21,102]).

9. In view of the clear framing of the Paris objective as well as the limited enforcement power and precision of other international environmental agreements, a new separate anchoring of plastics in international law does not appear to be absolutely necessary (in favour of an international plastic agreement $[10]$ as well as $[103,104]$ regarding marine plastics). Notwithstanding this, international standards for the biodegradability of plastics have to be established, since the biodegradability even of non-fossil fuels plastics is doubtful. This is because, like (almost) all current environmental problems, the problems of plastics inhere a global dimension and, therefore, are best addressed transnationally.

\section{Conclusions}

We have seen in this contribution: Legal initiatives that are able to address the ubiquitous plastic pollution in soils comprehensively do not exist thus far. Using the example of Germany and the European Union, it could be shown that the command-and-control legislation aiming at the protection of agricultural soils does not include sufficient mechanisms to protect the soils from the serious threat of plastic particles. In particular, plastic particles smaller than two or one millimetres are not covered by the current legislation, although they pose the major environmental burden. As there are no reliable methods for the determination of both micro- and nano-plastic particles in the soil and in organic fertilisers globally, the prerequisite for significantly strengthened command-and-control legislation in this respect is also missing. These methodical questions, as well as the determination of equivalent standards for the biodegradability of plastics, require intensive scientific research on a global level. 
Notwithstanding this, it could be shown that the major (global) challenge lies in the quantitative reduction of plastic inputs at its source, which is closely linked to the necessary transformation to a post-fossil society. Thus, economic policy instruments aiming at a phasing-out of fossil fuels will also effectively reduce the total plastic load entering the environment. The climate crisis and the rapidly growing plastic pollution in all environmental departments require the implementation of economic policy instruments-preferably on a broad geographical policy level. However, due to the potentially harmful consequences not only of fossil-fuel-based but also of bio-based plastics, additional command-and-control regulations remain necessary.

Author Contributions: J.S. was responsible for conceptualization, the review of natural scientific findings and main parts of governance analysis; F.E. headed the underlying project, contributed to methodological aspects, delivered the enhanced governance options and some conclusions. All authors have read and agree to the published version of the manuscript.

Funding: This research was funded by the German Federal Environment Agency (UBA) (No 003857133) and partly funded by the German Federal Ministry of Education and Research (BMBF) within the BonaRes project InnoSoilPhos (No 031B0509).

Acknowledgments: The authors gratefully acknowledge the German Federal Environment Agency for funding the project (No 003857133) and German Federal Ministry of Education and Research (BMBF) for funding the BonaRes project InnoSoilPhos (No 031B0509). We also thank our colleague Katharine Heyl for proofreading.

Conflicts of Interest: The authors declare no conflict of interest.

\section{References}

1. GESAMP (Joint Group of Experts on the Scientific Aspects of Marine Environmental Protection). Sources, Fate and Effects of Microplastics in the Marine Environment: A Global Assessment; IMO; FAO; UNESCO-IOC; UNIDO; WMO; IAEA; UN; UNEP; UNDP: London, UK, 2015; pp. 1-98.

2. Lambert, S.; Wagner, M. Environmental performance of bio-based and biodegradable plastics: The road ahead. Chem. Soc. Rev. 2017, 46, 6855-6871. [CrossRef] [PubMed]

3. Wang, J.; Liu, X.; Li, Y.; Powell, T.; Wang, X.; Wang, G.; Zhang, P. Microplastics as contaminants in the soil environment: A mini-review. Sci. Total Environ. 2019, 691, 848-857. [CrossRef] [PubMed]

4. Bertling, J.; Bertling, R.; Hamann, L. Kunststoffe in der Umwelt. Ursachen, Mengen, Umweltschicksale, Wirkungen, Lösungsansätze, Empfehlungen; Fraunhofer Institut für Umwelt-, Sicherheits- und Energietechnik Umsicht: Oberhausen, Germany, 2018; pp. 1-56.

5. European Commission. Proposal for a Regulation of the European Parliament and of the Council Establishing Rules on Support for Strategic Plans to be Drawn up by Member States under the Common Agricultural Policy (CAP Strategic Plans) and Financed by the European Agricultural Guarantee Fund (EAGF) and by the European Agricultural Fund for Rural Development (EAFRD) and Repealing Regulation (EU) No 1305/2013 of the European Parliament and of the Council and Regulation (EU) No 1307/2013 of the European Parliament and of the Council; European Commission: Brussels, Belgium, 2018.

6. United Nations Environmental Program (UNEP). Marine Plastic Debris and Microplastics: Global Lessons and Research to Inspire Action and Guide Policy Change; UNEP: Nairobi, Kenya, 2016; pp. 1-274.

7. Galgani, F.; Fleet, J.; Van Franeker, S.; Kastanevakis, T.; Maes, J.; Mouat, L.; Oosterban, I. Marine Strategy Framework Directive. Task Group 10 Report. Marine Litter; EU Commission, Joint Research Centre: Luxembourg, 2010; pp. 1-57.

8. De Souza Machado, A.A.; Kloas, W.; Zarfl, C.; Hempel, S.; Rillig, M.C. Microplastics as an emerging threat to terrestrial ecosystems. Glob. Change Biol. 2018, 24, 1405-1416. [CrossRef] [PubMed]

9. Gasperi, J.; Wright, S.L.; Dris, R.; Collard, F.; Mandin, C.; Guerrouache, M.; Langlois, V.; Kelly, F.J.; Tassin, B. Microplastics in air: Are we breathing it in? Curr. Opin. Environ. Sci. Health 2018, 1, 1-5. [CrossRef]

10. Simon, N.; Schulte, M.L. Stopping Global Plastic Pollution: The Case for an International Convention; Heinrich-Böll-Foundation: Berlin, Germany, 2017; pp. 1-56.

11. Browne, M.A.; Niven, S.J.; Galloway, T.S.; Rowland, S.J.; Thompson, R.C. Microplastic moves pollutants and additives to worms, reducing functions linked to health and biodiversity. Curr. Biol. 2013, 23, 2388-2392. [CrossRef] 
12. European Commission. Green Paper. On a European Strategy on Plastic Waste in the Environment; European Commission: Brussels, Belgium, 2013; pp. 1-20.

13. Briassoulis, D.; Degli Innocenti, F. Standards for soil biodegradable plastics. In Soil Degradable Bioplastics for a Sustainable Modern Agriculture. Green Chemistry and Sustainable Technology; Malinconico, M., Ed.; Springer: Berlin, Germany, 2017; pp. 139-168.

14. Rillig, M.C. Microplastic in terrestrial ecosystems and the soil? Environ. Sci. Technol. 2012, 46, 6453-6454. [CrossRef]

15. De Souza Machado, A.A.; Lau, C.W.; Kloas, W.; Bergmann, J.; Bachelier, J.B.; Faltin, E.; Becker, R.; Görlich, A.S.; Rillig, M.C. Microplastics can change soil properties and affect plant performance. Environ. Sci. Technol. 2019, 53, 6044-6052. [CrossRef]

16. Bläsing, M.; Amelung, W. Plastics in soil: Analytical methods and possible sources. Sci. Total Environ. 2017, 612, 422-435. [CrossRef]

17. Setälä, O.; Norkko, J.; Lehtiniemi, M. Feeding type affects microplastic ingestion in a coastal invertebrate community. Mar. Pollut. Bull. 2016, 102, 95-101. [CrossRef]

18. Tourinho, P.S.; Kočí, V.; Loureiro, S.; van Gestel, C.A.M. Partitioning of chemical contaminants to microplastics: Sorption mechanisms, environmental distribution and effects on toxicity and bioaccumulation. Environ. Pollut. 2019, 252, 1246-1256. [CrossRef]

19. Piehl, S.; Leibner, A.; Löder, M.G.J.; Dris, R.; Bogner, C.; Laforsch, C. Identification and quantification of macro- and microplastics on an agricultural farmland. Sci. Rep. 2018, 8, 17950. [CrossRef] [PubMed]

20. Scalenghe, R. Resource or waste? A perspective of plastics degradation in soil with a focus on end-of-life options. Heliyon 2018, 4. [CrossRef] [PubMed]

21. Ekardt, F. Sustainability. Transformation, Governance, Ethics, Law; Springer International Publishing: Basel, Switzerland, 2019; pp. 1-324.

22. Hennig, B. Nachhaltige Landnutzung und Bioenergie. Ambivalenzen, Governance, Rechtsfragen; Beiträge zur sozialwissenschaftlichen Nachhaltigkeitsforschung; Metropolis: Marburg, Germany, 2017; ISBN 978-3-7316-1266-7.

23. Ekardt, F. Nachhaltigkeit und Methodik: Verhaltensantriebe und Transformationsbedingungen ermitteln. Rev. D'Allem. Pays Lang. Allem. 2018, 50, 279-296. [CrossRef]

24. Paul, C.; Techen, A.-K.; Robinson, J.S.; Helming, K. Rebound effects in agricultural land and soil management: Review and analytical framework. J. Clean. Prod. 2019, 227, 1054-1067. [CrossRef]

25. United Nations. Adoption of the Paris Agreement (PA); United Nations: New York, NY, USA, 2015; pp. 1-27.

26. United Nations. Convention on Biodiversity (CBD); United Nations: New York, NY, USA, 1992; pp. 1-30.

27. Intergovernmental Panel on Climate Change (IPCC). Global Warming of $1.5^{\circ} \mathrm{C}$. An. IPCC Special Report on the Impacts of Global Warming of $1.5^{\circ} \mathrm{C}$ above Pre-Industrial Levels and Related Global Greenhouse Gas Emission Pathways, in the Context of Strengthening the Global Response to the Threat of Climate Change, Sustainable Development, and Efforts to Eradicate Poverty; IPCC: Geneva, Switzerland, 2019; pp. 1-630.

28. Ekardt, F.; Wieding, J.; Zorn, A. Paris agreement, precautionary principle and human rights: Zero emissions in two decades? Sustainability 2018, 10, 2812. [CrossRef]

29. Gasser, T.; Guivarch, C.; Tachiiri, K.; Jones, C.D.; Ciais, P. Negative emissions physically needed to keep global warming below $2{ }^{\circ} \mathrm{C}$. Nat. Commun. 2015, 6, 7958. [CrossRef]

30. Smith, P.; Davis, S.J.; Creutzig, F.; Fuss, S.; Minx, J.; Gabrielle, B.; Kato, E.; Jackson, R.B.; Cowie, A.; Kriegler, E.; et al. Biophysical and economic limits to negative $\mathrm{CO}_{2}$ emissions. Nat. Clim. Change 2016, 6, 42-50. [CrossRef]

31. Garske, B.; Stubenrauch, J.; Ekardt, F.; Weisse, C.F.; Lorenz, M. Kunststoff-Governance im europäischen Kreislaufwirtschafts- und Stoffrecht. Z. Umweltr. 2020, 4, 215-225.

32. Ekardt, F.; Jacobs, B.; Stubenrauch, J.; Garske, B. Peatland governance: The problem of depicting in sustainability governance, regulatory law, and economic instruments. Land 2020, 9. [CrossRef]

33. Weishaupt, A.; Ekardt, F.; Garske, B.; Stubenrauch, J.; Wieding, J. Land use, livestock, quantity governance, and economic instruments-Sustainability beyond big livestock herds and fossil fuels. Sustainability 2020, 12, 2053. [CrossRef]

34. Garske, B.; Stubenrauch, J.; Ekardt, F. Sustainable phosphorus management in European agricultural and environmental law. Rev. Eur. Comp. Int. Environ. Law 2020, 29, 107-117. [CrossRef] 
35. European Chemicals Agency (ECHA). Annex XV Restriction Report. Proposal for a Restriction: Intentionally Added Microplastics; ECHA: Helsinki, Finland, 2019; pp. 1-146.

36. Stubenrauch, J. Phosphor-Governance in Ländervergleichender Perspektive-Deutschland, Costa Rica, Nicaragua. Ein Beitrag zur Nachhaltigkeits- und Bodenschutzpolitik; Beiträge zur sozialwissenschaftlichen Nachhaltigkeitsforschung; Metropolis: Marburg, Germany, 2019; pp. 1-490.

37. Stubenrauch, J.; Garske, B.; Ekardt, F. Sustainable land use, soil protection and phosphorus management from a cross-national perspective. Sustainability 2018, 10, 1988. [CrossRef]

38. Philibert, C. Producing Industrial Hydrogen from Renewable Energy; International Energy Agency (IEA): Paris, France, 2017.

39. Sutton, M.A.; Bleeker, A.; Howard, C.M.; Bekanda, M.; Grizetti, B.; de Vries, W.; van Grivsen, H.J.M.; Abrol, Y.P.; Adha, T.K.; Davidson, E.A.; et al. Our Nutrient World. The Challenge to Produce More Food and Energy with Less Pollution. Global Overview of Nutrient Management; Centre for Ecology and Hydrology: Edinburgh, Scotland, 2013; pp. 1-128.

40. Ekardt, F.; Wieding, J.; Garske, B.; Stubenrauch, J. Agriculture-related climate policies-law and governance issues on the European and global level. Carbon Clim. Law Rev. 2018, 12, 316-331. [CrossRef]

41. Havlin, J.L.; Kissel, D.E.; Maddux, L.D.; Claassen, M.M.; Long, J.H. Crop rotation and tillage effects on soil organic carbon and nitrogen. Soil Sci. Soc. Am. J. 1990, 54, 448-452. [CrossRef]

42. Hobley, E.U.; Honermeier, B.; Don, A.; Gocke, M.I.; Amelung, W.; Kögel-Knabner, I. Decoupling of subsoil carbon and nitrogen dynamics after long-term crop rotation and fertilization. Agric. Ecosyst. Environ. 2018, 265, 363-373. [CrossRef]

43. Sokouti, R.; Kaveh, A.; Parvizi, Y. Modeling of soil carbon storage capacity using farm management factors in drylands. Agric. For. 2017, 63, 153-165. [CrossRef]

44. Kole, P.J.; Löhr, A.J.; Van Belleghem, G.A.J.F.; Ragas, M.J.A. Wear and tear of tyres: A stealthy source of microplastics in the environment. Int. J. Environ. Res. Public Health 2017, 14, 1265. [CrossRef]

45. Weithmann, N.; Möller, J.N.; Löder, M.G.J.; Piehl, S.; Laforsch, C.; Freitag, R. Organic fertilizer as a vehicle for the entry of microplastic into the environment. Sci. Adv. 2018, 4. [CrossRef]

46. Carr, S.A.; Liu, J.; Tesoro, A.G. Transport and fate of microplastic particles in wastewater treatment plants. Water Res. 2016, 91, 174-182. [CrossRef]

47. Haernvall, K.; Zitzenbacher, S.; Biundo, A.; Yamamoto, M.; Schick, M.B.; Ribitsch, D.; Guebitz, G.M. Enzymes as enhancers for the biodegradation of synthetic polymers in wastewater. ChemBioChem 2018, 19, 317-325. [CrossRef]

48. Tagg, A.S.; Labrenz, M. Closing microplastic pathways before they open: A model approach. Environ. Sci. Technol. 2018, 52, 3340-3341. [CrossRef] [PubMed]

49. Synthetische Polymere. Available online: https://www.bde.de/themen/biomasse/klaerschlamm/synthetischepolymere/ (accessed on 17 April 2020).

50. Nizzetto, L.; Futter, M.; Langaas, S. Are agricultural soils dumps for microplastics of urban origin? Environ. Sci. Technol. 2016, 50, 10777-10779. [CrossRef] [PubMed]

51. Möller, K. Assessment of Recycled Phosphorus Fertilizers for Organic Farming: Chars, Ashes and Slags; ETH Zurich, FiBL, Bioforsk, BOKU, Newcastle University, University of Copenhagen: Zurich, Switzerland, 2016; pp. 1-7.

52. Bridle, T.R.; Pritchard, D. Energy and nutrient recovery from sewage sludge via pyrolysis. Water Sci. Technol. 2004, 50, 169-175. [CrossRef] [PubMed]

53. Schoumans, O.F.; Bouraoui, F.; Kabbe, C.; Oenema, O.; van Dijk, K.C. Phosphorus management in Europe in a changing world. Ambio 2015, 44, 180-192. [CrossRef] [PubMed]

54. Leinweber, P.; Bathmann, U.; Buczko, U.; Douhaire, C.; Eichler-Löbermann, B.; Frossard, E.; Ekardt, F.; Jarvie, H.; Krämer, I.; Kabbe, C.; et al. Handling the phosphorus paradox in agriculture and natural ecosystems: Scarcity, necessity, and burden of P. Ambio 2018, 47, 3-19. [CrossRef]

55. Celik, I.; Ortas, I.; Kilic, S. Effects of compost, mycorrhiza, manure and fertilizer on some physical properties of a Chromoxerert soil. Soil Tillage Res. 2004, 78, 59-67. [CrossRef]

56. Schulz, H.; Dunst, G.; Glaser, B. Positive effects of composted biochar on plant growth and soil fertility. Agron. Sustain. Dev. 2013, 33, 817-827. [CrossRef]

57. Kehres, B. Kunststoffe in Kompost und Gärprodukten. Herkunft-Bedeutung-Vermeidung; Humus und Kompost aktuell Q4; Federal Compost Association: Cologne, Germany, 2018; pp. 4-6. 
58. Orhan, Y.; Hrenovic, J.; Büyükgüngör, H. Biodegradation of plastic compost bags under controlled soil conditions. ACTA Chim. Slov. 2004, 51, 579-588.

59. German Federal Compost Association. Kompostierung von ,Biokunststoffen' ist ein Irrweg. Positionspapier der Bundesgütegemeinschaft Kompost (BGK) vom 21.03.2014; German Federal Compost Association: Cologne, Germany, 2014; pp. 1-4.

60. Iwata, T. Biodegradable and bio-based polymers: Future prospects of eco-friendly plastics. Angew. Chem. Int. Ed. 2015, 54, 3210-3215. [CrossRef]

61. Makowski, D. Mapping the evidence on the environmental impacts of land-use change for non-food biomass production. In Sustainable Agriculture Reviews; Rechauchere, O., Bispo, A., Gabrielle, B., Makowski, D., Eds.; Springer: Zurich, Switzerland, 2018; pp. 39-78.

62. Kubowicz, S.; Booth, A.M. Biodegradability of plastics: Challenges and misconceptions. Environ. Sci. Technol. 2017, 51, 12058-12060. [CrossRef]

63. European Union. Directive (EU) 2019/904 of the European Parliament and of the Council of 5 June 2019 on the Reduction of the Impact of Certain Plastic Products on the Environment OJ L 155 of 12.06.2019; European Union: Brussels, Belgium, 2019; pp. 1-119.

64. Heck, V.; Gerten, D.; Lucht, W.; Popp, A. Biomass-based negative emissions difficult to reconcile with planetary boundaries. Nat. Clim. Change 2018, 8, 151-155. [CrossRef]

65. European Commission (DG Environment). Intentionally Added Microplastics in Products; Final Report; European Commission (DG Environment): London, UK, 2017; pp. 39-78.

66. Pietra, L.D. The EU's Push for Biodegradable Polymers in Mineral Fertilizers, Fertilizer Focus; Fertilizers Europe: Brussels, Belgium, 2019; pp. 1-2.

67. United States Congress. Federal Soil Conservation Act (Gesetz zum Schutz vor schädlichen Bodenveränderungen und zur Sanierung von Altlasten (BBodSchG)) of 17.03.1998, Last Revised by Art. 3 Para. 3 of the Regulation of 27.09.2017, Federal Law Gazette I p. 3465; United States Congress: Washington, DC, USA, 1998.

68. United States Congress. Soil Conservation Ordinance (Bundesbodenschutz- und Altlastenverordnung (BBodSchV)) of 12.07.1999, Federal Law Gazette I S. 1554, last revised by Art. 3 Para. 4 of the Regulation of 27.09.2017, Federal Law Gazette I p. 3465; United States Congress: Washington, DC, USA, 1999.

69. Möller, J.N.; Löder, M.G.J.; Laforsch, C. Finding microplastics in soils: A review of analytical methods. Environ. Sci. Technol. 2020, 54, 2078-2090. [CrossRef] [PubMed]

70. He, D.; Luo, Y.; Lu, S.; Liu, M.; Song, Y.; Lei, L. Microplastics in soils: Analytical methods, pollution characteristics and ecological risks. TrAC Trends Anal. Chem. 2018, 109, 163-172. [CrossRef]

71. Zhu, D.; Chen, Q.-L.; An, X.-L.; Yang, X.-R.; Christie, P.; Ke, X.; Wu, L.-H.; Zhu, Y.-G. Exposure of soil collembolans to microplastics perturbs their gut microbiota and alters their isotopic composition. Soil Biol. Biochem. 2018, 116, 302-310. [CrossRef]

72. Van Gestel, C.A.M.; Selonen, S. Ecotoxicological effects of microplastics in soil: Comments on the paper by Zhu et al. (2018) 'Exposure of soil collembolans to microplastics perturbs their gut microbiota and alters their isotopic composition'. Soil Biol. Biochem. 2018, 124, 116-117. [CrossRef]

73. Zhu, D.; Ke, X.; Christie, P.; Zhu, Y.-G. Rejoinder to "Comments on Zhu et al. (2018) Exposure of soil collembolans to microplastics perturbs their gut microbiota and alters their isotopic composition". Soil Biol. Biochem. 2018, 124, 275-276. [CrossRef]

74. European Union. Regulation (EC) No 2003/2003 of the European Parliament and of the Council of 13.10.2003 Relating to Fertilisers, OJ L 304 of 21.11.2003, p. 1, Last Revised by Regulation (EC) No 162/2007 of the Commission of 19.02.2007, OJ 2007 L 51; European Union: Brussels, Belgium, 2007; p. 7.

75. European Union. Regulation (EU) 2019/1009 of the European Parliament and of the Council of 5 June 2019 Laying down Rules on the Making Available on the Market of EU Fertilising Products and Amending Regulations (EC) No 1069/2009 and (EC) No 1107/2009 and Repealing Regulation (EC) No 2003/2003 OJ L 170/1 of 25.06.2019; European Union: Brussels, Belgium, 2019; pp. 1-114.

76. United States Congress. Council Directive 86/278/EEC of 12 June 1986 on the Protection of the Environment, and in Particular of the Soil, When Sewage Sludge is Used in Agriculture OJ L 181/6 of 04.07.1986; United States Congress: Washington, DC, USA, 1986. 
77. European Union. Regulation EC No 1907/2006 of the European Parliament and of the Council of 18 December 2006 Concerning the Registration, Evaluation, Authorisation and Restriction of Chemicals (REACH), Establishing a European Chemicals Agency, Amending Directive 1999/45/EC and Repealing Council Regulation (EEC) No 793/93 and Commission Regulation (EC) No 1488/94 as well as Council Directive 76/769/EEC and Commission Directives 91/155/EEC, 93/67/EEC, 93/105/EC and 2000/21/EC, OJ L 396 of 30.12.2006; European Union: Brussels, Belgium, 2006; p. 1.

78. Douhaire, C. Rechtsfragen der Düngung. Eine Steuerungs- und Rechtswissenschaftliche Analyse vor dem Hintergrund Unions- und Völkerrechtlicher Verpflichtungen und Politischer Zielsetzungen zum Umwelt- und Ressourcenschutz; Schriften zum Umweltrecht; Duncker \& Humblot: Berlin, Germany, 2019; pp. 1-329.

79. Garske, B. Ordnungsrechtliche und Ökonomische Instrumente der Phosphor-Governance; Unter Berücksichtigung der Wirkungen auf Böden, Gewässer, Biodiversität und Klima; Metropolis: Marburg, Germany, 2020; pp. 1-517.

80. Federal Law Gazette. German Fertiliser Ordinance (Verordnung über das Inverkehrbringen von Düngemitteln, Bodenhilfsstoffen, Kultursubstraten und Pflanzen-hilfsmitteln (DüMV)) of 05.12.2012, Federal Law Gazette I p. 2482, Last Revised by Art. 1 of the Regulation of 02.10.2019; Bundesanzeiger Verlagsgesellschaft mbH: Cologne, Germany, 2019; p. 1414.

81. Federal Law Gazette. German Fertiliser Act (Düngegesetz (DüngG)) of 09.01.2009, Federal Law Gazette I p. 54, 136, Last Revised by Art. 1 of the Regulation of 05.05.2017, Federal Law Gazette I; Bundesanzeiger Verlagsgesellschaft mbH: Cologne, Germany, 2017; p. 1068.

82. Federal Compost Association. Methodenbuch zur Analyse Organischer Düngemittel, Bodenverbesserungsmittel und Substrate. Methodenbuch Kapitel II C 1 "Fremdstoffgehalt". Loseblattsammlung, 4. Ergänzungslieferung, 12/2015; Federal Compost Association: Cologne, Germany, 2015; pp. 1-11.

83. Schwaferts, C.; Niessner, R.; Elsner, M.; Ivleva, N.P. Methods for the analysis of submicrometer- and nanoplastic particles in the environment. TrAC 2019, 112, 52-65. [CrossRef]

84. Oliveira, M.; Almeida, M. The why and how of micro(nano)plastic research. TrAC 2019, 114, $196-201$. [CrossRef]

85. Federal Law Gazette. Sewage Sludge Ordinance (Verordnung über die Verwertung von Klärschlamm, Klärschlammgemisch und Klärschlammkompost (AbfKlärV)) of 27.09.2017, Federal Law Gazette I p. 3465, Last Revised by Art. 6 of the Regulation of 27.09.2017; Bundesanzeiger Verlagsgesellschaft mbH: Cologne, Germany, 2017; p. 3465.

86. German Federal Ministry for the Environment, Nature Conservation and Nuclear Safety (BMU). Deutsches Ressourceneffizienzprogramm II. Programm zur Nachhaltigen Nutzung und zum Schutz der Natürlichen Ressourcen; BMU: Berlin, Germany, 2016.

87. Federal Law Gazette. Ordinance on the Reorganisation of Sewage Sludge Recycling (Verordnung zur Neuordnung der Klärschlammverwertung) of 27.09.2017; Bundesanzeiger Verlagsgesellschaft mbH: Cologne, Germany, 2017; p. 3465.

88. European Union. Directive 2008/98/EG of the European Parliament and of the Council of 19.11.2008 on Waste and Repealing Certain Directives, OJ 2008 No L 31 2/3; European Union: Brussels, Belgium, 2008.

89. European Union. Directive (EU) 2018/851 of the European Parliament and of the Council of 30 May 2018 amending Directive 2008/98/EC on waste, OJ L 150/109 of 14.06.2018; European Union: Brussels, Belgium, 2018.

90. Federal Law Gazette. Circular Economy Act (Gesetz zur Förderung der Kreislaufwirtschaft und Sicherung der Umweltverträglichen Bewirtschaftung von Abfällen (KrWG)) of 24.02.2012, Federal Law Gazette I p. 212, Last Revised by Art. 2 Para. 9 of the Regulation of 20.07.2017; Bundesanzeiger Verlagsgesellschaft mbH: Cologne, Germany, 2017; p. 2808.

91. Federal Law Gazette. Commercial Waste Ordinance (Verordnung über die Bewirtschaftung von Gewerblichen Siedlungsabfällen und von Bestimmten Bau- und Abbruchabfällen (GewAbfV)) of 18.04.2017, Federal Law Gazette I p. 896, Last Revised by Art. 2 Para. 3 of the Regulation of 05.07.2017; Bundesanzeiger Verlagsgesellschaft mbH: Cologne, Germany, 2017; p. 2234.

92. Federal Law Gazette. Bio-Waste Ordinance (Verordnung über die Verwertung von Bioabfällen auf Landwirtschaftlich, Forstwirtschaftlich und Gärtnerisch Genutzten Böden (BioAbfV)) of 04.04.2013, Federal Law Gazette I p. 658, Last Revised by Art. 3 Para. 2 of the Regulation of 27.09.2017; Bundesanzeiger Verlagsgesellschaft mbH: Cologne, Germany, 2017; p. 3465. 
93. State Agency for the Environment; Ministry of the Environment Baden-Württemberg. Ergänzende Vollzugshinweise für Baden-Württemberg zur LAGA Mitteilung 34 zur Gewerbeabfallverordnung; State Agency for the Environment/Ministry of the Environment Baden-Württemberg: Stuttgart, Germany, 2019.

94. Garske, B.; Heyl, K.; Ekardt, F.; Weber, L.M.; Gradzka, W. Challenges of food waste governance. Sustainability. under review.

95. Kasza, G.; Szabó-Bódi, B.; Lakner, Z.; Izsó, T. Balancing the desire to decrease food waste with requirements of food safety. Trends Food Sci. Technol. 2019, 84, 74-76. [CrossRef]

96. Tsang, Y.F.; Kumar, V.; Samadar, P.; Yang, Y.; Lee, J.; Ok, Y.S.; Song, H.; Kim, K.-H.; Kwon, E.E.; Jeon, Y.J. Production of bioplastic through food waste valorization. Environ. Int. 2019, 127, 625-644. [CrossRef] [PubMed]

97. European Union. Directive (EU) 2018/852 of the European Parliament and of the Council of 30 May 2018 Amending Directive 94/62/EC on Packaging and Packaging Waste OJ 2018 L 150/151 of 14.06.2018; European Union: Brussels, Belgium, 2018; pp. 141-154.

98. European Commission. Soil 2020. Available online: https://ec.europa.eu/environment/soil/index_en.htm (accessed on 17 April 2020).

99. Federal Working Group Fertilisation (Bundesarbeitskreis Düngung (BAD). Neues Düngemittelrecht in Europa-Bedeutung für die Landwirtschaft; BAD: Frankfurt, Germany, 2018.

100. Bosnjak, N. Ein Emissionshandelssystem der ersten Handelsstufe Rechtliche, Politische und Ökonomische Aspekte eines Gesetzgebungsvorschlags; Metropolis: Marburg, Germany, 2015; Volume 16, pp. 1-362.

101. Plastics Europe. How Plastics are Made. Available online: https://www.plasticseurope.org/en/about-plastics/ what-are-plastics/how-plastics-are-made (accessed on 13 May 2020).

102. Susnjar, D. Proportionality, Fundamental Rights and Balance of Powers; Martinus Nijhoff Publishers: Leiden, The Netherlands, 2010; pp. 1-389.

103. Raubenheimer, K.; Mcllgorm, A.; Oral, N. Towards an improved international framework to govern the life cycle of plastics. Rev. Eur. Comp. Int. Environ. Law 2018, 27, 210-221. [CrossRef]

104. Kirk, E.A.; Popattanachai, N. Marine plastics: Fragmentation, effectiveness and legitimacy in international lawmaking. Rev. Eur. Comp. Int. Environ. Law 2018, 27, 222-233. [CrossRef]

(C) 2020 by the authors. Licensee MDPI, Basel, Switzerland. This article is an open access article distributed under the terms and conditions of the Creative Commons Attribution (CC BY) license (http://creativecommons.org/licenses/by/4.0/). 